\title{
Under What Conditions Would the Orthodox Engage in the Judeo-Christian Dialogue?
}

\author{
SANDRINE CANERI*
}

The official dialogue between Churches and Judaism began between the two world wars, in America and then in England and intensified after the Second World War, reaching most Western European countries. The Eastern Churches felt estranged from this dialogue led by the Western Churches, as they have neither the same approach, nor the same history, nor the same texts of reference. This is why the Orthodox Churches wish to enter the dialogue according to their own approach, relying on their own texts, and recontextualizing the Fathers of Church when they speak about Judaism. By basing the dialogue on the origins of the Church, the Orthodox can justify why certain liturgical texts are obsolete and harmful to the Christian conscience. They will also be able to show how their tradition is close to and in continuity with the Jewish tradition. By doing so, they will be sensitive to the rebuilding of the unique people of God, composed of Christians and Jews according to the Epistle to the Ephesians (2.14)

Keywords: Judeo-Christian Dialogue, Judeo-Catholic dialogue, Orthodox approach, Fathers of the Church and Jews, Soloviev, Boulgakov, Ecumenism

Judeo-Christian dialogue originated and developed in the West ${ }^{1}$ following the Second World War. ${ }^{2}$ When speaking of dialogue, we are specifically referring to official dialogue between two communities, and not simply that between notable individuals, as such dialogue has existed since the foundation of the Christian community. Sadly, the fruits of such personal exchanges have most often left no trace on Church history, or on the people of God. But how is it that this official dialogue, born in 20th century America then spread into Western Europe, has had little to no influence on the countries of Eastern Europe? Why?

\footnotetext{
"Sandrine Caneri, Teacher in patristic exegesis, St. Serge Institute of Orthodox Theology (Paris). Address: 48 route de Cuxac, 11600 Villardonnel, France, e-mail: sandrine.caneri@orange.fr 1 The American association, now called ICCJ (International Council of Christians and Jews), was founded in 1928 as the National Council of Christians and Jews. ICCJ now brings together thirty-eight organizations and meets annually in a major city to continue the meetings and common study.

2 Outside the ICCJ, dialogues existed between the two wars, see: Rémy Guérinel: “Traces d'un dialogue bienveillant dans l'entre-deux-guerres", in: Sens 394 (12/2014), p. 793-802. Already alive before the second war, the dialogue reached a decisive stage from 1947 and the decades that followed.
} 
We must consider the historical and political context of Eastern Europe. First, although much has changed in the last century, the majority of the Eastern Europe population is Orthodox, ${ }^{3}$ for whom interreligious dialogue has not been an important element of its tradition. It is also to be noted that communism divided Europe in two and cut the East off from the West along with its developments in interreligious dialogue, and suppressed religion in general. This left the East about 50 years behind the religious changes happening in the West.

Finally, it is important to consider that following the totalitarian Nazi regime which systematically exterminated Jewish communities; very few Jews remained in Eastern Europe after WWII, a decisive moment in the birth of Judeo-Christian dialogue.

These historical and political questions are obviously essential to understand this phenomenon, but they are not sufficient in themselves. We will seek a better understanding of why the Orthodox are reluctant to engage in dialogue with the Jews. What are the major issues that make this dialogue difficult for them? What are the conditions that would foster and enrich such a dialogue?

\section{Differing Situations for the Orthodox in East and West}

At the beginning of the 20th century, vast emigrations from Eastern to Western Europe and America saw the foundation of new Orthodox communities who established churches in the West. These emigrations started with Romania, Russia and Greece, and were followed by many others. ${ }^{4}$ Today these communities make part of the official religious landscape of the West, distinct from Catholics and Protestants, yet it has taken years for them to gain visibility and legitimacy among Western Christian nations.

This state of affairs, the novelty of Orthodox Christians in the West, has not been simple for the welcomed nor for the welcomers. The newcomers from the East have had a legitimate need to establish their communities, to create their structures, put in place theological training and so forth. Given the challenges of these demands, has it really been possible for them to extend themselves further for interreligious dialogue? And as for traditionally Orthodox countries, is it not reasonable to consider that they have needed to dedicate their time and resources to their post-communist reconstruction?

We must then consider the reality that these last decades in which Judeo-Christian dialogue was born and developed in the West, have been,

3 We know that Poland, Hungary, Latvia, Slovakia, Lithuania, Croatia and Croatia have a majority of Catholic or Protestant Christians.

4 Serbia, Georgia, Lebanon, Syria, etc. 
for the Orthodox, a time dedicated to the edification and stabilization of its churches on both sides of the European continent and the United States. Thus, in realistic terms, the question of Judeo-Christian dialogue for the Orthodox Church is very new and has only recently become a real issue.

The advancement of this dialogue, its globalization and mediatisation interpellate the Orthodox Church which can no longer stand apart. But in the East, these churches have no model to undertake such a dialogue nor do they know how they would prefer to approach it. In addition to this, there remain very few surrounding Jewish communities with whom to enter into dialogue. The only model for dialogue is that which developed in the West and persists to this day.

Several fundamental questions challenge the Orthodox Church in both the East and the West:

1. Can one realistically undertake an official dialogue with the Jews given that they are few among us, regrouped in communities, and when the territories we inhabit are vast and travel is difficult?

2. Is this Western model of dialogue beneficial for Orthodox churches, whether they are situated in the West or the East? ${ }^{5}$

3. Can the historical, liturgical or theological specificities of the Orthodox Church be taken into account by the parameters of the dialogue already established by the Western churches, given the particularities of its approach and perspective?

4. Is Judeo-Christian dialogue first and foremost an encounter between individuals belonging to two communities, or the occasion for a theological reflection on the unity of the two Testaments and Jewish heritage in the Orthodox tradition?

\section{Jewish-Christian dialogue in France, a predominantly Catholic country}

Let us take the example of France, a country whose framework for dialogue is unique because it takes place in a secular political structure. The Orthodox Church has been settled in France for more than a century and a half, and the Orthodox now have an established history in this land. Several Orthodox Christians are available and ready to engage in this dialogue and have made some first advances. Their bishops have engaged with the only existing structure, the AJCF, ${ }^{6}$ and have sent an Orthodox representative. The problem is that this association is of a Catholic majority and all its presup-

\footnotetext{
5 The word "orthodox" or "orthodoxy" in this article will only apply to Orthodox Christians. If we are to speak of "orthodox Judaism" in distinction to other currents of Judaism, we will specify this.

6 The Judeo-Christian Friendship of France.
} 
positions are Catholic. ${ }^{7}$ How can the Orthodox, such a small minority in this country, make their voices heard? Does their tradition offer a specific approach to this dialogue?

Let us now look at the major presuppositions of Jewish-Catholic dialogue:

1. Since the end of the Second Vatican council, that is to say 50 years ago, there have been many official and magisterial texts concerning the links between the Catholic Church and the Synagogue. These, having become normative for Catholics, are constantly mentioned as a roadmap for dialogue. ${ }^{8}$ Naturally, it is difficult for the Orthodox to adopt them; for their theology does not always reflect that of the Orthodox Church, nor do they have authority for the Orthodox. If the majority of the dialogue turns around these texts, how can the Orthodox find their place?' Will they not simply be absorbed and submerged by the Catholics?

2. In France, the AJCF was co-founded in 1948 by Jews, Catholics and Protestants, with one Orthodox participant. The Jewish historian Jules Isaac became the dominant influence in this association, with singularly historical and political conceptions of dialogue that remain to this day. They are based on the review of Christian history which reveals the slander, affronts and humiliations that the Jewish people have suffered during the two thousand years history of Christianity, leading to the worst tragedy of our time, the Shoah.

3. In several of his works, Jules Isaac denounced the "teaching of contempt" against the Jews transmitted through Christian catechesis, Sunday homilies or courses in theology. ${ }^{10}$ The aim of the dialogue was to correct this.

7 Sometimes some Protestant voices are also heard.

8 Les Églises devant le judaïme. Documents officiels 1948-1978, Textes rassemblés, traduits et annotés par Marie-Thérèse Hoch et Bernard Dupuy, Paris, Cerf 1980; Jean Dujardin, L'Église catholique et le peuple juif. Un autre regard, Paris, Calmann-Lévy 2003; B. Dupuy, Quarante ans d'études sur Israël. Pensée juive et pensée chrétienne en dialogue, Paris, Parole et Silence 2008; Pierre Lenhardt, A l'écoute d'Israël en Église, 2 tomes, Paris, Parole et silence 2006, 2009; Paule Berger Marx, Les relations entre les juifs et les catholiques dans la France de l'après-guerre, 1945-1965, Paris, Parole et Silence 2009, etc.

9 Surprisingly, we see that the Protestant communities are doing quite well with these texts, which do not concern them any more, than we do.

10 Jules Isaac, Jésus et Israël, Paris, Albin Michel 1948. Second edition revised by the author: Paris, Fasquelle 1959. Recent edition: Paris, Grasset 1970. André Kaspi, Jules Isaac ou la passion de la vérité, Paris, Plon 2002, quotes Jules Isaac: "I came to the conviction that this received tradition, taught for hundreds of years by thousands and thousands of voices, was the first and permanent source, the powerful and secular strain on which all other varieties of antisemitism-even the most contrary-had been grafted." p.180-181. 
4. In his perspective, this "teaching of contempt" begins with the Holy Fathers of the Church and is spread through them to the present day. The Holy Fathers are therefore despised, and discussion of them excluded, so violent are their words against the Jews. These teachings are considered to be the origin of modern antiSemitism which directly engendered the Shoah. ${ }^{11}$

This model of dialogue initiated by the AJCF is grounded on indisputable historical facts. It bears no contradiction and therefor it is not open, for the time being, to any parallel approach.

Faced with such presuppositions the Orthodox are paralyzed by fear. They have trouble measuring the impact of the Shoah on the Jews, all of whom have lost family members in the concentration camps and have been traumatized for generations. The Orthodox do not recognize any "teaching of contempt" in their churches. They cannot and will not remove the holy Fathers from their teachings, and see no link between them and modern antiSemitism. They are unaware of what the word "Christian" signifies to a Jew and do not perceive anything in their liturgical corpus that is humiliating to Jews. The Orthodox wish to be in a relationship, but without any real contact.

\section{On what basis should dialogue begin?}

Is the situation the same in traditionally Orthodox countries? Until we have been in personal contact with a Jew, we cannot have much awareness of the history of our two communities, nor can we know what is in the hearts and minds of today's Jews towards Christians.

Only through personal contact and respect can we be awakened and motivated to act. But should we question our own theology? This is the greatest point of contention, which hinders Orthodox engagement in dialogue. It can also be a point of contention with Western Christians. The Orthodox cannot engage in a sincere dialogue with the Jews by removing fundamental sources of Christian theology. We do not want this because our theology is part of the Revelation, and it will never be subject to negotiation.

Another difficult point is the accusations we have to face. This political and historical model constrains us to identify as personally responsible for the reprehensible acts that some Christians committed against some Jews over the course of history, or even recognize ourselves as responsible for the Shoah, or acknowledge ourselves as executioners. This leaves us perplexed and uncomfortable. We wish to inaugurate a sincere, frank and loyal dialogue, which takes into account contentious historical issues, but also moves beyond them.

\footnotetext{
11 See the collective work: Auwers Jean-Marie et al. (eds.), L'antijudaïsme des Pères, mythe et/ ou réalité ?, Théologie historique 125, Paris, Beauchesne 2017, p. 125.
} 


\section{Several factors that hinder the engagement of the Orthodox in this dialogue}

The first is a lack of relationship, both on a personal level and also on the ecclesial and communal levels. Where to meet? How to create peaceful relationships? Do we know how to respectfully approach Jews and welcome their history and tradition? Do we have any preconceived ideas about them that do not foster relationships?

Then comes the difficulty of recognizing the indelible wounds committed by members of our churches from the origins to recent tragic history. And if we do bear responsibility for these wounds, must we acknowledge them as a community- for in the Church we all bear the sins of our brothers.

The tendency in our Church in this centuries-long dispute is to blame the Jews for their attitude toward the Christian Church, which they have not always respected. V. Soloviev, writing in the $19^{\text {th }} \mathrm{c}$., warned us against this tendency and challenged Christians to first look at their own behaviour: "If we cannot behave as Christians towards all, without exception for the Jews, then we are entirely guilty when we do not. Christianity has never behaved in a Christian way towards the Jews." ${ }^{2}$

Another question concerns the stumbling and embarrassment caused by the language the Church uses concerning Jews and Judaism in general. How have we understood this, and how have we transmitted these words for centuries? Are there verbal excesses in the Patristic texts? If so, they should not, in any way, be taken out of context or even exported as "divine words" for our time. This is a major difficulty.

Has there really been a "teaching of contempt" for Jews in our churches? Do our churches continue to teach that Jews are guilty of "deicide" and that the church has definitively replaced Israel? If so, we must understand that these two statements are not respectful of the Jewish people and therefore we must consider correcting them. This is what the Archbishop of Cyprus, Mgr Chrysostomos, did. ${ }^{13}$

12 Published in Russian in 1884, Vladimir Soloviev, Le Judaïsme et la question Chrétienne, translated into French in 1955, Paris, Desclée, p. 56-57, reissued in 1992.

13 On December 6, 2011, Yona Metzger, Chief Rabbi of Israel signed a historic declaration in Nicosia with Archbishop Chrysostomos, Primate of the Church of Cyprus, affirming the illegitimacy of the doctrine of Jewish collective guilt for Jesus' deicide. This is the first time that an Orthodox church has explicitly rejected this doctrine, which has been one of the major factors in the development of religious anti-Semitism in Europe. Another important provision of this declaration concerns proselytism within the respective communities, it is incompatible with mutual respect. In the context of this declaration, the two personalities also committed themselves to strengthening relations between the Church and the Jewish people. 
Is it acceptable to maintain texts in our liturgical services that are disrespectful to the Jews, in particular those of Holy Week? Can we really pray to the One who created us all in His image while incriminating those who do not share our faith, but transmitted to us the essence of the Revelation?

In an article written in 1998, Fr Sergei Alekseyevich Hackel wrote:

The liturgical texts of Great and Holy Friday are considered to accurately express the doctrine of the Church. However, their authority is based only on their age-old use. These texts have never been sanctioned by ecumenical councils for modification or removal, so there is no need for the approval of a new council. Reforms of this kind have already been proposed many times, for example in 1960 by the Greek theologian Hamilcar Alivazatos. However, to this day, nothing has changed, and we continue to give our assent to these texts, beyond the standards received. We lack humility, perseverance, academic knowledge and above all, determination. ${ }^{14}$

For all these reasons, the vast majority of Orthodox Christians may not yet be ready to engage in dialogue with Jews.

\section{Are the Orthodox ready to engage in this dialogue?}

While the Orthodox would like to enter into sincere and mutually respectful dialogue with the Jews, the question remains of whether they are prepared to be challenged in their certainties? First, they will have to accept historical truths that disturb them and contradict certain Patristic writings.

Some early, foundational Christian thought is challenged by history. The Fathers predicted the extinction of Judaism following the destruction of the Temple and the disappearance of Jews beyond Judea. However, the Jewish people have continued to multiply and bear fruit throughout the world over the past two thousand years.

The accusation of "deicide" which the Jews endured is also easily contradicted by historical fact. Only a handful of Jews out of the two million in the land of Judea at the time of Christ were even present at the time and place where He was crucified, not to mention the vast numbers of Jews outside of Judea, the diaspora, which amounted to 5 or 6 million in the first century. ${ }^{15}$ Finally, the torture of the cross is a Roman tool of torment,

14 "Je suis Joseph votre frère" / "I am Joseph your brother", in: SOP suppl. 226 B (3/1998). Father Sergei was a priest in England in the Russian diocese of Souroge.

15 J. Isaac, “D’un antisémitisme chrétien qui est anti-chrétien et, à cet égard d'un redressement nécessaire de l'enseignement chrétien”, in: Sens 420 (9-10/ 2018), p. 431. 
indicating a strong Roman implication in the death of Christ and distributes responsibility widely. ${ }^{16}$

Do the Orthodox continue to affirm that the Church has replaced Israel, substituting itself for Israel? Do they still claim that God revoked His covenant with the people of Israel and transferred His promises to His Church?

If this is so, how is it that this small nation has survived to this day, having suffered so much torment and tragedy? So many populations, civilizations and powerful empires have disappeared, could God not make the Jewish people disappear as well if this were His will? Much to the contrary, the whole of history shows that "God's gifts and call are without repentance" (Rom 11:29). He clearly continues to bestow His blessings on His people even if they are not more perfect than others, and maybe not even better than others.

Are the Orthodox ready to re-examine all the stereotypes that persist about Jews and their traditions?

\section{How do the Orthodox wish to engage in this dialogue?}

In England, the United States and France, members of the Orthodox Church have addressed and revised negative attitudes and statements about Jews, and are ready to engage in dialogue. In France, they tried to join the AJCF, but never managed to make their voices heard, nor their convictions respected. Rather, they found that in addition to the difficulty of dialogue with the Jews, there was the added difficult of divergence with the Catholics and Protestants at the head of this dialogue.

Thus, the other essential factor for the Orthodox to enter into a real dialogue with the Jews is respect for Orthodox theology, liturgical practices and Christian way of life. They need direct encounter with the Jewish community in order to establish their proper understanding of Judaism, through their unique Christian tradition, and not that imposed by Western traditions. Of greatest importance is fair consideration for our Patristic tradition as an essential element of Orthodox theology. Arguably, the Jews are wellplaced to understand the Orthodox on this account; they too believe that their written Torah is one with the oral Torah. That is to say is one with the commandments contained in the Talmud, the Midrash and later masters, which together influence and determine their tradition and communal values. Likewise, we Orthodox have the tradition of the Holy Fathers. Through

16 On this point, many studies have been done: Peter J. Tomson, Simon Légasse, Qui a tué Jésus?, Lire la Bible, Paris, Cerf 2004. Not to mention that the Jewish leaders are mainly those of the priestly caste. 
their participation in the seven ecumenical councils, their exegesis of the two Testaments, and their influence on our liturgical corpus and moral understanding and behaviour, ${ }^{17}$ they have become for us a source inseparable from the Scriptures.

Just as Jews do not dialogue with us without taking into account their oral Torah, so we cannot enter into dialogue without the study of the Patristic corpus, a corpus set aside by the Western churches because they consider it unbearable and abhorrent on the subject of Jews.

It is here that the real difficulties arise for the Orthodox. Although several books have been published in the recent decades on the texts of the Holy Fathers concerning the question of the Jews, ${ }^{18}$ there is a lot of work in front of us. Perhaps it is the magnitude of the task that now fills us with fear.

The work ahead of us is enormous. We must both maintain our attachment and admiration for the Fathers without losing our critical sense and not accept the entirety of their writings, as some of their ideas are no longer adapted to our times. It is therefore a question of education in discernment, to be neither Patrophobe nor Patrophile, ${ }^{19}$ but in the just veneration of our Fathers and their holiness. A saint is never perfect, and we must accept that even the Fathers can make mistakes. ${ }^{20}$

In the same way, minority and contradictory opinions are kept in the Talmud, while the community has chosen an opinion that is consensus, so we should not be affected by the fact that some of the words of the Holy Fathers have been rejected.

17 We can also include Holy Ascetics.

18 Nicholas de Lange, Origen and the Jews. Studies in Jewish-Christians relations in third century Palestine, Oriental publication 25, Cambridge, Cambridge University Press 1976; Marc Hirshman, A Rivalry of Genius. Jewish and Christian Biblical Interpretation in Late Antiquity, Batya Stein [Hebrew Translation], New York, State University Press of New York 1996; Robert L. Wilken, John Chrysostom and the Jews. Rhetoric and reality in the late 4th century, Eugen, Oregon, Wipf and Stock Publishers 2004; Paula Fredriksen, Augustine and the Jews. A Christian Defense of Jews and Judaism, New Haven, Yale University press 2010; Elena Narinskaya, Ephrem a 'Jewish' Sage. A Comparison of the Exegetical Writings of St. Ephrem the Syrian and Jewish Traditions, Studia Traditionis Theologiae 7, Turnhout, Brepols 2010; Sébastien Morlet et al (eds.), Les dialogues adversus ivdaeos. Permanences and mutations of a controversial tradition, Proceedings of the international conference organized on 7 and 8 December 2011 at the University of Paris-Sorbonne, Études Augustiniennes. Antique Series 196, Paris, Institut d'Études Augustiniennes 2013, etc.

19 We refer to the two in-depth studies on this subject by Laurent Kloeble, "Note sur Jean Chrysostome et les Juifs", in: Sens 384 (12/2013), p. 837-842; idem, "Les Pères de l'Église. Les impensés du dialogue judéo-chrétien”, in: Sens 369 (5/2012), p. 379-403.

20 Father Serge Bulgakov showed that many Fathers made mistakes, and that the Church knew how to discern them without hitting them with anathema, see: S. Bulgakov, Le Buisson ardent, Paris, L'Âge d'homme 1990, p. 9. 


\section{Why is this dialogue fundamental for the Orthodox?}

Jewish-Christian dialogue is fundamental for all Christians, but it is particularly important for the Orthodox, for Judaism is the very root of Christianity. It is the foundation of the Christian faith. Moreover, it was through the Jewish people that the Messiah, Christ, wanted to be born, to live, to transmit his message, to die and rise again. He lived his life as a Jew, and His teaching is addressed to the Jews, using their culture and their language. How can we understand the words of our Master if we do not know the religious, spiritual and cultural references of this Jewish tradition?

For example, when the Gospel speaks of the "journey of the Sabbath", do we know what that signifies? Or in more general terms, do we concretely know what the rest of Sabbath consisted of, that the holy women observed beginning at the evening of Holy Friday? Do we know what work was not permitted on the Sabbath at the time of Christ? The knowledge of these rules would help us to better understand the controversies between Jesus with certain Jews, Pharisees, doctors of the Law and Scribes concerning the healing that he performed on the Sabbath, which in reality were not prohibited. Do we know the form and content of the three daily prayers of Judaism, and the traces they left on our Byzantine liturgy? Do we know the principal feasts of Judaism? Do we know why we have maintained some of them, keeping their original meaning but also adding a layer of Christian meaning to them, while others have been transformed, or divided and included in other feasts, or simply not maintained at all? Do we correctly understand the word "nomos" in the Septuagint and in the Gospels, along with the words "parabole" and "paroimia" or even "dunamis" and "semeion"? Are we aware of the testimony of St. Irenee who tells us that Matthew wrote his gospel "in the language of the Hebrews?" 21 Words that hold important implications for the study of the Gospels.

What was the meaning of sickness and death in the Judaism in the first century? How were they understood? Did the Jews believe in the resurrection of the dead, and if so, how? What was the significance of the expression "the Son of Man" for a Jew at the time of Daniel? What meaning does Jesus give to this expression when he applies it to himself? We could multiply the questions, and still several articles would not suffice to address all of them. Whole books could be written to try to respond to these questions according to our knowledge and the advancement of scholarly research.

Thus, the objective of dialogue is not only to encounter the other, the other we think we know because the Gospels speak of him, but who in reality is completely different than the image we've made for ourselves. This

21 Irenaeus of Lyon, Contre les Hérésies, III, 2, 1, Paris, Cerf 1984, p. 277. 
dialogue disrupts our preconceived notions and reveals our ignorance. But the objective of dialogue is also to know ourselves better, to deepen our own traditions, to realize to what extent Christianity is built on the foundations of Judaism, and sometimes in strong opposition to it. It consists of understanding the construction of two identities that mirror one another. ${ }^{22}$

\section{Conclusion}

Coming back to the initial question of this article, we can conclude that if the conditions for dialogue could be met, this dialogue would bear much fruit.

1. The Orthodox would gain awareness of their preconceived, often erroneous, ideas about the Jews of the New Testament, and thus the importance of dialogue in order to truly understand their own scriptures.

2. In encountering the Jews, the Orthodox will appreciate the immense treasure of the Jewish tradition from which it directly and greatly inherited.

3. Instead of considering the Judaism as an opponent even hostile religion to Christianity, the Orthodox will penetrate much more subtly into the understanding of the mystery of Israel, whose fidelity to the Torah and its commandments may awaken in them a new fervour to follow Christ's commandments.

4. Jewish fervour for the One God implies absolute fidelity to the commandments of the Torah. They are the way to remain united to Him, to live in total dependence on God, and to expect everything from Him. For the Jews know perfectly well that observance of the commandments does not provide salvation, but is a way of purifying the heart and approaching God.

He who studies the Torah fulfils a commandment. He who studies and keeps it fulfils two commandments. Whoever studies it, keeps it and lives it has reached the top. ${ }^{23}$

Rabba bar Rav Huna said: Any person who has Torah in him but does not have fear of Heaven is like a treasurer [gizbar] to whom they gave keys to the inner doors of the treasury but they did not give keys to the outer door. With what key will he enter?

22 A great deal of literature on this subject has been published in recent decades. See for example: Marie-Anne Vannier (ed.), Judaïsme et christianisme chez les Pères, Judaïsme ancien et origines du christianisme 8, Turnhout, Brepols 2015; Dan Jaffé, Le talmud et les origines juives du christianisme. Jésus, Paul et les judéo-chrétiens dans la littérature talmudique, Initiations bibliques, Paris, Cerf 2007.

23 Sifré Dt on Deut. 11.22, $\$ 48.12$. 
Rabbi Yohanan adds that anyone who keeps the commandments of the Torah, his soul is preserved. ${ }^{24}$

Does the Christian know that?

Let us consider a contemporary initiative: Etgar Lefkovits published an article in the Jerusalem post on April 20, 2007 entitled: "Priests: Remove anti-Semitic liturgy". ${ }^{25}$ It begins as follows:

A group of 12 Orthodox priests have called on their Church to review its longstanding theological positions towards Jews and the State of Israel, and to excise anti-Semitic passages from its liturgy.

At the end of the article he says: "Now, however, some Orthodox Christian intellectuals feel their Church needs revival and that this has to start at the roots: reconciliation with the Jews." The text of this statement was written in Russian. ${ }^{26}$ The signatories, who in reality are not all priests, had met in Jerusalem. They came from Russia, Ukraine, Georgia, Greece and Italy. For them the liturgy includes some Judeophobic passages that are incompatible with Christianity. We will conclude by opening a question: are we aware of the division of Christian churches?

The more we become aware, the more we perceive the extent to which such division has been influenced and conditioned by the protoschism of history, the internal division of the one people of God into two distinct traditions. According to Dom Nicholas Oehmen, the union of the Churches will only be fully realized once the two divided parts of Israel have reunited. ${ }^{27}$ The division of the Church, according to Paul Demann, will only be resolved by the reunification of the Church and Israel ${ }^{28}$. For the Church needs the people of the first Covenant to recover its lost unity, and it needs to be reintroduced into a united people of God, in the image of the One and Only God. ${ }^{29}$

As the Talmud explains it so well:

The Holy One, blessed be He, said unto Israel: "You have made me one in the world and I will make you one in the world. You

24 Tamuld Babli Shabbat 31b and Tamuld Babli Menahot 99b.

25 https://www.jpost.com/ArticleArchive/ListArticleArchive.aspx? viewed on April 20, 2007.

26 The SOP in French-language had taken over the main elements of the SOP. See: SOP 219 (6/2007), p. 17-18.

27 Nicholas Oehmen, "Le schisme dans le cadre de l'économie divine", in: Irénikon 21 (1948), p. 6-31.

28 Paul Démann, "Israël et l'unité de l'Église", in: Cahiers Sioniens 1 (3/1953), p. 1-24.

29 There are many books and articles on this subject. See again: John Oesterreicher (ed.), The Bridge: A Yearbook of Judaeo-Christian Studies, vol. 1, New York, Pantheon Books 1955; Daniel Marguerat, Le Déchirement. Juifs et chrétiens au premier siècle, Le monde de la Bible 32, Genève, Labor et Fidès 1996. 
Sandrine Caneri

have made me one in the world, as it is stated: "Hear, Israel, the Lord is our God, the Lord is One" (Deut. 6.4). And (because of this) I will make you one in the world, as it is said: "Who is like Your people, Israel, people one on the earth" (2 Sam. 7.23; $1 \mathrm{Chr}$. 17.21). ${ }^{30}$

For Christ came not only "to gather in unity the scattered children of God" (Jn. 11.52), but also and precisely to make For he is our peace; in his flesh he For he is our peace; in his flesh he has made both groups into one and has broken down the dividing wall, that is, the hostility between us. (Eph 2:14)

30 Tamuld Babli, Berakhot 6a. 